\title{
樹林帯に作用する土砂・水混相流の流体力と土砂堆皘 \\ Drag Forces of Solid-Liquid Mixture Flows on Multiple Rows of Cylinders
}

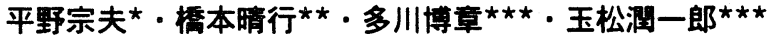

\section{By Muneo HIRANO, Haruyuki HASHIMOTO, Hiroaki TAGAWA and Jun-ichiro TAMAMATSU}

\begin{abstract}
Flow behaviour of sand-water mixtures and clear water is experimentally examined in an open channel with cylinders installed across the whole channel width in their multiple rows. Cylinders are placed in stagger with their equal spacing on the fixed bed. Drag coefficient of a cylinder in the mixture and clear-water flows is determined from the measurements of average velocity and flow depth. Drag coefficient increases with sediment concentration and arrangement density of cylinders. Sand deposition occurrs in the case when channel bed slope is mild and bed material is coarse. Sand deposition develops in the downstream area at steeper slopes and in the upstream area in the case of coarser material.
\end{abstract}

Keywords : sand-water mixture flow, drag force, drag coefficient,

\section{1.はじめに}

樹林帯は水害防備林、飛砂防備林、防雪林など防災的機能を持つものとして古くから利用されてきたが、 最近、自然環境的な側面からも注目されるようになり、その機能について定量的な研究が行われるようになっ てきた。土石流や土砂流などの土砂災害に対しても、良好な環境空間を創造しつつ、土砂堆積を促進して下 流域への土砂流出を防ぎ、地域の安全を計るものとして、各地で樹林帯が計画されている。たとえば阪神・ 淡路大震災で壊滅的被害を受けた神戸市の復興計画では山麓緑地带構想が提言され”、市街地に隣接する六 甲山系山簏斜面に樹林帯の設置が計画されている。このような計画に際しては, 土石流などと樹林帯との相 互作用に関する定量的な評価が問題となるが、これについては2 3の研究があるだけで2.3)、定量的な評価 までには至っていない。

本研究は、以上のような観点から水路に樹林帯の模型を設置し、土砂・水の混相流を樹林帯に流入させて その流動特性を調べたものである。まず、樹林帯内に堆砂が発生しない場合は樹林帯の抗力係数を求め、土 砂濃度や樹林帯特性パラメータとの関連性を調べた。次に、樹林帯内に堆砂が発生する場合は土砂堆積の縦 断形状を調べ、最後に、土砂堆積に対する樹林帯特性パラメータの効果を調べるため河床変動計算を行った。

\begin{tabular}{lllllll}
\hline$*$ & 正会員 & 工博 & 九州大学教授 & 工学部建設都市工学科（テ812 & 福岡市東区箱崎6-10-1） \\
$* *$ & 正会員 & 工博 & 九州大学助教授 & 工学部建設都市工学科 ( & 同 & 上 \\
$* * *$ & 学生会員 & & 九州大学大学院修士課程水工土木学専攻（ & 同 & 上
\end{tabular}




\section{2. 実験方法}

実験に使用した水路は2種類で、ひとつは全長 $12 \mathrm{~m}$ 、 幅 $\mathrm{B}=12.5 \mathrm{~cm}$ の両側アクリルライト製、他のひとつは 全長 $12 \mathrm{~m}$ 、幅 $\mathrm{B}=15 \mathrm{~cm}$ の片側アクリルライト製の可変 勾配水路である。上流側 $7 \mathrm{~m}$ は移動床、下流側 $5 \mathrm{~m}$ は固 定床とし、さらに下流端から長さLの区間には全水路 幅にわたって樹林帯を設置した。前者の水路では $\mathrm{L}=$ $1.9 \mathrm{~m}$ 、後者の水路では $\mathrm{L}=3 \mathrm{~m}$ とした（図 - 1）。

樹木の模型としては、直径 $D=4.2 \mathrm{~mm}$ 釘および $D=$ $4.0 \mathrm{~mm}$ と $2.0 \mathrm{~mm}$ のステンレス丸棒を用いた。樹木は、 中心間隔が $3.3 \mathrm{~cm} 、 5 \mathrm{~cm} 、 6 \mathrm{~cm}$ の3種類で、千鳥状に配 置した。円柱密度 $\lambda$ (河床単位面積に占める円柱の断 面積）、密生度a（単位体積あたりの円柱の遮蔽面積） は表・1のようになる。なお、樹林帯 $\mathrm{A} 、 \mathrm{~B}$ では幅 $\mathrm{B}=$ $12.5 \mathrm{~cm}$ 水路を使用し、樹林帯C、D、Eでは幅 $B=15$ omの水路を使用した。

河床材料には、粒径 $\mathrm{d}=0.17 \mathrm{~mm}$ 、密度 $\sigma=2.61 \mathrm{~g}^{\circ} \mathrm{cm}^{3}$ の均一な細砂および粒径 $\mathrm{d}=0.87 \mathrm{~mm}$ 、密度 $\sigma=2.62$ $\mathrm{g}_{\mathrm{om}} \mathrm{cm}^{3}$ 粒径 $\mathrm{d}=1.9 \mathrm{~mm}$ 、密度 $\sigma=2.61 \mathrm{~g} \mathrm{~cm}^{3}$ の均一な粗 砂を用いた。

予備実験によると、細砂を用いた急勾配の実験では、 樹林帯に堆砂が発生しないが、紘勾配の実験や粗砂を 用いた場合には堆積が発生したりする。そこで実験は 大別して2種類行った。ひとつは堆積が発生しない場 合における樹林帯の抗力の実験（表 - 2) であり、他の ひとつは樹林帯内における流れの表面・堆積形状を調 ベる実験である（表 - 3）。

実験ではまず、水路に河床材料を敷き、所定の勾配 $\theta_{0}$ に設定した後、上流端から単位幅流量 $\mathrm{q}_{\mathrm{p}}$ の水を供 給した。その結果、土砂・水の混相流が発生・流下し、 樹林帯内に流入した。さらに、堆積を防ぐため、水路 途中から清水 $\mathrm{q}_{\mathbf{p}}$ を注き、土砂濃度を減少させて樹林帯

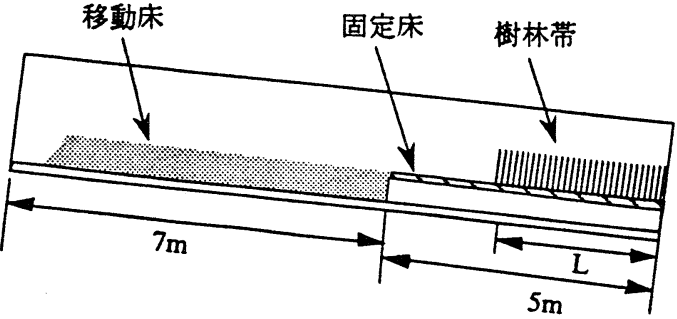

図-1 水路の模式図 $(\mathrm{L}=1.9 \mathrm{~m} 、 3 \mathrm{~m})$

表-1 樹林帯の特性

\begin{tabular}{|c|c|c|c|c|c|}
\hline 種類 & A & B & C & D & E \\
\hline $\mathrm{D}(\mathrm{mm})$ & 4.2 & 2.0 & 4.0 & 2.0 & 2.0 \\
\hline$\lambda$ & $1.1 \times 10^{-2}$ & $2.5 \times 10^{-3}$ & $7.0 \times 10^{-3}$ & $5.7 \times 10^{-3}$ & $1.7 \times 10^{-3}$ \\
\hline $\mathrm{a}(1 / \mathrm{cm})$ & 0.0336 & 0.016 & 0.0222 & 0.036 & 0.0111 \\
\hline $\mathrm{B}(\mathrm{cm})$ & 12.5 & 12.5 & 15 & 15 & 15 \\
\hline $\mathrm{L}(\mathrm{m})$ & 1.9 & 1.9 & 3 & 3 & 3 \\
\hline
\end{tabular}

表 - 2 樹林带の抗力係数を調べる実験

\begin{tabular}{|c|c|c|c|c|}
\hline 種類 & $d(\mathrm{~mm})$ & $q_{\mathrm{D}}\left(\mathrm{cm}^{2} / \mathrm{s}\right)$ & $q_{\mathrm{ps}}\left(\mathrm{cm}^{2} / \mathrm{s}\right)$ & $\theta_{0}(\circ)$ \\
\hline $\mathrm{A}$ & 0.17 & 100 & 0 & 10 \\
\hline $\mathrm{A}$ & 0.17 & 200 & 0 & $6,8,10$ \\
\hline $\mathrm{A}$ & 0.17 & 100 & 50,100 & 6,10 \\
\hline $\mathrm{B}$ & 0.17 & 200 & 0 & $6,8,10$ \\
\hline $\mathrm{C}$ & 0.17 & 200 & 0 & $6,8,10$ \\
\hline $\mathrm{D}$ & 0.17 & 200 & 0 & 10 \\
\hline E & 0.17 & 200 & 0 & $6,8,10$ \\
\hline
\end{tabular}

表 - 3 樹林帯における表面・堆積形状を調べ実験

\begin{tabular}{|c|c|c|c|c|}
\hline 種頪 & $d(\mathrm{~mm})$ & $\boldsymbol{q}_{\mathbf{p}}\left(\mathrm{cm}^{2} / \mathrm{s}\right)$ & $q_{\mathrm{ps}}\left(\mathrm{cm}^{2} / \mathrm{s}\right)$ & $\theta_{0}(\oint)$ \\
\hline$A$ & 0.17 & 100 & 0 & 3 \\
\hline$A$ & 0.17 & 200 & 0 & $3,6,10$ \\
\hline$A$ & 1.9 & 100 & 0 & 10 \\
\hline$A$ & 1.9 & 200 & 0 & 3,6 \\
\hline C & 0.17 & 200 & 0 & 3 \\
\hline C & 0.87 & 200 & 0 & 3,6 \\
\hline D & 0.17 & 200 & 0 & 3,8 \\
\hline E & 0.17 & 200 & 0 & 3 \\
\hline
\end{tabular}
に流入させる実験も行った。下流端では、流れを採取

して、土砂と水を合わせた全流量、流砂量をそれぞれ測定した。また，側方からはビデオカメラを用いて 樹林帯内外の水深および流れの状況を撮影した。さらに比較のため、混相流と同じ流量の清水を樹林帯に 流入させて上記と同様な計測を行った。

\section{3.実験結果}

\section{1 樹林帯の抗力係数}

樹林帯内外の断面における連続式、運動方程式はそれぞれ

$$
\begin{aligned}
& \mathrm{q}_{\mathrm{t}}=\mathrm{v}_{0} \mathrm{~h}_{0}=(1-\lambda) \mathrm{vh} \quad(1) \quad \rho_{\mathrm{t}} \mathrm{gh}_{0} \mathrm{~B} \sin \theta_{0}=\rho_{\mathrm{t}} \frac{\mathrm{v}_{0}^{2}}{\phi_{0}^{2}}\left(\mathrm{~B}+2 \mathrm{~h}_{0}\right) \\
& \rho_{\mathrm{t}}(1-\lambda) \operatorname{ghB} \sin \theta_{0}=\rho_{\mathrm{t}} \frac{\mathrm{v}^{2}}{\phi^{2}}\{\mathrm{~B}(1-\lambda)+2 \mathrm{~h}\}+\frac{\rho_{\mathrm{t}}}{2} \mathrm{v}^{2} \mathrm{C}_{\mathrm{Dah}} \mathrm{B}
\end{aligned}
$$


ここに、h、B、 $\phi 、 \mathrm{C}_{\mathrm{D}}$ はそれぞれ水深、水路 幅、流速係数および抗力係数である。また添 字0は樹林帯の外の断面を表わす。上式におい て、 $\phi=\phi_{0}$ として、樹林帯の抗力係数 $\mathrm{C}_{\mathrm{D}}$ を求め ると、図－2となる。同図には比較のため単独 円柱の抗力係数も示している.5. 。データにバラ゙キ があるが、抗力係数 $\mathrm{C}_{\mathrm{D}}$ は、土砂輸送濃度 $\mathrm{C}_{\mathrm{T}}$ が大 きくなると、大きくなることが分かる。また、 単独円柱の抗力係数よりも樹林帯の抗力係数 のほうが大きいことも分かる。図-3、4は、清 水流及び混相流の場合について、抗力係数 $\mathrm{C}_{\mathrm{D}}$ と樹林帯密度入との関係をそれぞれ示してい る。ここに、 $\lambda=0$ における $\mathrm{C}_{\mathrm{D}}$ は単独円柱のデー 夕を比較のため示したものである。清水流の 場合も混相流の場合も、樹林帯密度が大きく $\mathrm{C}_{\mathrm{D}}$ なると、抗力係数は増加する傾向にある。ま た、単独円柱の場合はひずみゲージを用いて 測定した抗力から決定された抗力係数である が、式(1)、(2)、(3)を用いて評価した結果と整 合性の良い值を示している。

\section{2 樹林带における堆砂形状}

図 - 5に、細砂を用いた場合の土砂の堆積形 状の時間的変化を示す。ここに、 $\mathrm{t}=0$ は樹林 帯上流端に流れが流入を開始した時間を表し ている。図-6は、図-5の場合より樹林帯密度

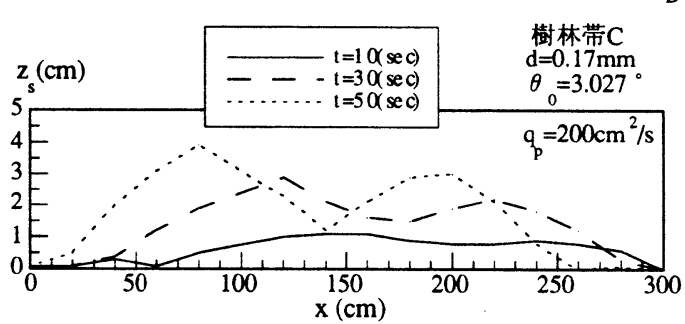

図 -5 細砂を用いた場合の樹林帯Cにおける堆 砂形状の時間的な変化

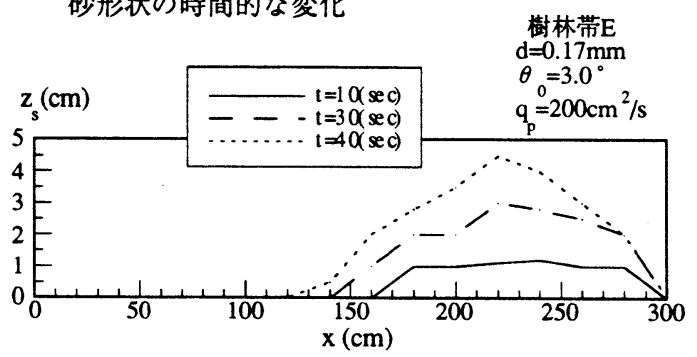

図 - 6 細砂を用いた場合の樹林帯Eにおける堆 砂形状の時間的な変化

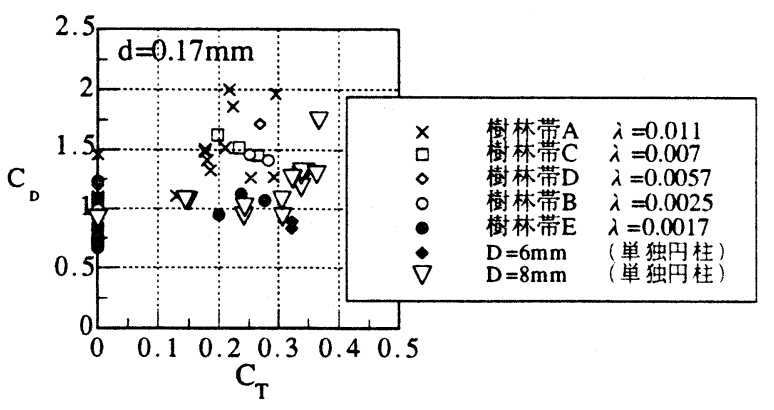

図 - 2 樹林帯の抗力係数と土砂濃度 $\mathrm{C}_{\mathrm{T}}$ との関係

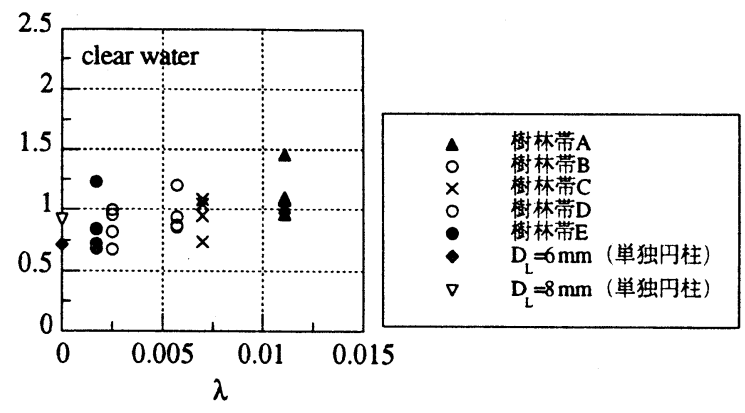

図 - 3 清水流の場合における樹林帯の抗力係数と 樹林帯密度との関係

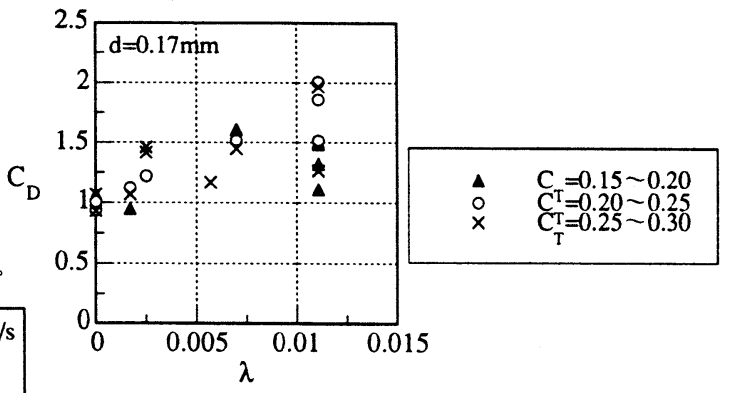

図 - 4 土砂・水混相流における樹林帯の抗力係 数と樹林帯密度との関係

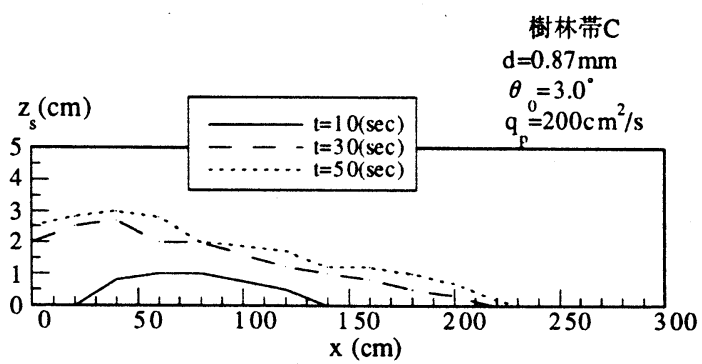

図 - 7 粗砂を用いた場合の樹林帯Cにおける堆 砂形状の時間的な变化 
が小さい場合の堆積形状を示す。また、図 - 7は、図 - 5の場合より材料が粗い場合における堆砂形状を示 す。堆砂の発生域は、樹林帯密度が小さくなると下流側へ、材料が粗くなると上流側へとそれぞれ移動す ることが分かる。

\section{4. 堆砂形状に関する考察}

\section{1 基礎式}

図 - 8 に樹林帯における堆砂状況の模式図を示す。樹林帯内における運動方程式、連続式はそれぞれ次の ように表される。

$$
\begin{aligned}
& \frac{\partial \mathrm{q}_{\mathrm{t}}}{\partial \mathrm{t}}+\frac{\partial \mathrm{vq}_{\mathrm{t}}}{\partial \mathrm{x}}=(1-\lambda) \mathrm{gh}\left[\sin \theta_{0}-\frac{\partial(\mathrm{h}+\mathrm{z})}{\partial \mathrm{x}} \cos \theta_{0}\right]-(1-\lambda) \frac{\mathrm{v}^{2}}{\phi^{2}}-\frac{1}{2} \mathrm{v}^{2} \mathrm{C}_{\mathrm{D}} \mathrm{ah} \\
& (1-\lambda) \frac{\partial(\mathrm{h}+\mathrm{z})}{\partial \mathrm{t}}+\frac{\partial \mathrm{q}_{\mathrm{t}}}{\partial \mathrm{x}}=0 \\
& (1-\lambda) \frac{\partial(\mathrm{C} * \mathrm{z})}{\partial \mathrm{t}}+\frac{\partial \mathrm{q}_{\mathrm{s}}}{\partial \mathrm{x}}=0 \\
& \text { ここに、t：時間、 } \mathrm{x} \text { : 元河床に沿った流れ方向の座標、 } \theta_{0}:
\end{aligned}
$$
水路床勾配、 $\mathrm{q}_{1}$ ：土砂と水を合わせた全流量、 $\mathrm{h} ：$ 水深、 $\mathrm{z}$ : 土砂 堆積厚、 $\lambda:$ 樹林帯密度（河床単位面積に占める樹木の断面積）、 $\mathrm{a}$ ：密生度（流体単位体積あたりの樹木の遮蔽面積）、 $\phi:$ 流速

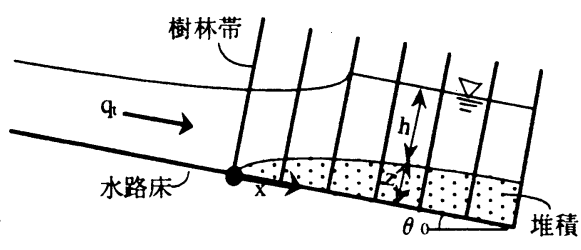

図 -8 樹林帯における堆砂状況の模式図 係数、 $\mathrm{C}_{\mathrm{D}}$ : 抗力係数、 $\mathrm{g}$ : 重力加速度、C.：堆積層における土砂 濃度でC. $=0.6 、 \mathrm{q}_{\mathrm{s}}$ : 流砂量である。

流砂形態として掃流砂を取り扱うこととすると、流砂量式は急勾配河道の掃流砂に適した橋本・平野の 式をを若干変形した次式を用いる。

$$
\frac{\mathrm{q}_{\mathrm{s}}}{\sqrt{\mathrm{sgd}^{3}}}=4.7 \tau_{*}^{3 / 2}\left(1-\frac{\tau_{* \mathrm{c}}}{\tau_{*}}\right) \frac{1}{\left(\alpha-\mathrm{I}_{\mathrm{f}}\right)}
$$

ここに、s: 土粒子の水中比重、 $\mathrm{d}:$ 粒径、 $\tau .:$ 無次元掃流力、 $\tau_{*}$ : 限界掃流力、 $\mathrm{I}_{\mathrm{f}}$ : 摩擦勾配、 $\alpha:$ 粒子

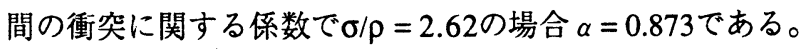

\section{2 数值計算法と初期・境界条件}

基礎式(4)～(6)において未知数は全流量 $\mathrm{q}_{\mathrm{i}}$ 、水深 $\mathrm{h} 、$ 河床高zの3個である。差分化にはMac Cormack 法を用い た。計算対象区間は $\mathrm{x}=-100 \mathrm{~cm} \sim 200 \mathrm{~cm}$ の区間である。区間 $\mathrm{x}=-100 \mathrm{~cm} \sim 0 \mathrm{~cm}$ は樹林帯のない固定床とし、座 標原点 $\mathrm{x}=0 \mathrm{~cm}$ を樹林帯の上流端とする。

初期条件としては、清水流の場合について全区間で定常状態となるまで計算を行い、この計算結果の水深 $\mathrm{h}$ と全流量 $\mathrm{q}$ 、を初期值とする。また、河床高については $\mathrm{z}=0$ を初期值とする。

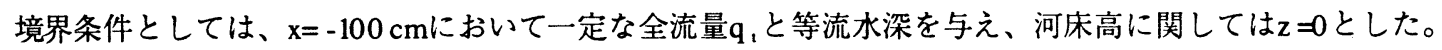
下流端の $\mathrm{x}=200 \mathrm{~cm}$ では通常のボックス型差分を陽解法となるように修正して用いた。

計算格子間隔は、計算区間の全縦断面にわたりクーラン数が1以下であるように $\Delta \mathrm{x}=2 \mathrm{~cm} 、 \Delta \mathrm{t}=0.01 \mathrm{sec}$ とした。

\section{3 計算結果および考察}

\section{（1）清水流の場合}

まず、簡単のために、樹林帯Aの清水流の場合について水面形の計算を行い実験值と比較した。樹林帯の 特性パラメー夕は樹林帯密度 $\lambda=0.011$ 、密生度 $\mathrm{a}=0.0336(1 / \mathrm{cm})$ である。抗力係数 $\mathrm{C}_{\mathrm{D}}$ 、流速係数 $\phi$ および境 
界条件の流量q、水深hを表 - 4に示す。図 - 9にその計算結果と 実験值との比較を示す。

$\theta=3^{\circ}$ の場合、計算結果は射流から常流に跳水を介して遷移し ている。 $\theta=6^{\circ}$ の場合の計算結果は、全領域で射流となり下流 に行くに従い等流水深に漸近している。いずれもほほ実験結果 と一致している。

表 - 4 清水流の水面形の計算条件

\begin{tabular}{|c|c|c|c|c|}
\hline$\theta_{0}$ & $\mathrm{C}_{\mathrm{D}}$ & $\phi$ & $\mathrm{q}_{\mathrm{t}}\left(\mathrm{cm}^{2} / \mathrm{s}\right)$ & $\mathrm{h}(\mathrm{cm})$ \\
\hline $3^{\circ}$ & 1.08 & 17.9 & 264 & 1.62 \\
\hline $6^{\circ}$ & 0.96 & 16.5 & 298 & 1.58 \\
\hline
\end{tabular}

\section{（2）擩流砂流の場合}

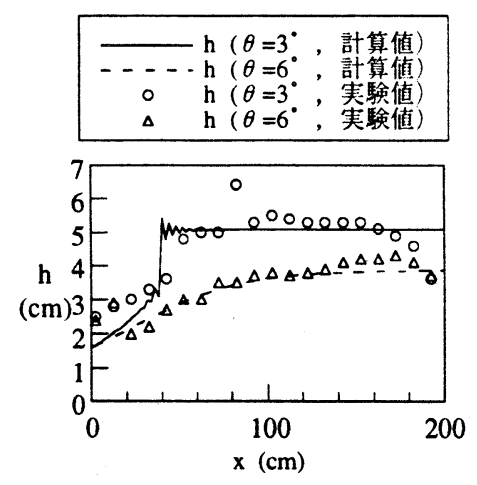

図 - 9 樹林帯内における清水流の水面形

堆砂形状への抗力係数や樹林帯特性パラメー夕の影響を調べるため、河床変動計算を行った。まず、樹林 帯密度 $\lambda=0.007$ 、密生度 $\mathrm{a}=0.0222(1 / \mathrm{cm})$ の樹林帯Cの場合について、抗力係数 $\mathrm{C}_{\mathrm{D}}$ 変化させて式(4) (6)の 数值計算を行い、土砂堆積に対するその効果を調べた。境界条件は流量 $\mathrm{q}_{\mathrm{t}}=208 \mathrm{c} \mathrm{m}^{2} / \mathrm{s}, \mathrm{h}=1.91 \mathrm{~cm}$ とした。 この樹林帯モデルは、直径 $4.0 \mathrm{~mm}$ の円柱を $6 \mathrm{~cm}$ 間隔で千鳥状に配置したものに相当する。計算条件を表 - 5 に示す。

表 - 5 堆砂形状の計算条件

\begin{tabular}{|c|c|c|c|c|c|c|c|}
\hline$\theta$ & $\mathrm{d}(\mathrm{mm})$ & $\sigma\left(\mathrm{g} / \mathrm{cm}^{3}\right)$ & $\mathrm{C}_{\mathrm{D}}$ & $\phi$ & $\mathrm{q}_{\mathrm{l}}\left(\mathrm{cm}^{2} / \mathrm{s}\right)$ & $\mathrm{h}(\mathrm{cm})$ & $\tau_{*_{\mathrm{c}}}$ \\
\hline $3^{\circ}$ & 0.87 & 2.62 & $1.0,1.5$ & 11 & 208 & 1.91 & 0.05 \\
\hline
\end{tabular}

図 - 10は、初期状態の水面形の計算結果で、樹林帯上流端を $\mathrm{x}=0 \mathrm{~cm}$ としている。なお、抗力係数 $\mathrm{C}_{\mathrm{D}}$ の值 は1.0、1.5と変化させている。 $C_{D}=1.0$ の場合は全領域で射流の状態で等流水深に漸近するが、 $\mathrm{C}_{\mathrm{D}}=1.5$ の場合 は跳水を介して射流から常流へ遷移している。この結果を初期条件として30秒後の堆砂形状を計算したも のが図 - 11 である。 $\mathrm{C}_{\mathrm{D}}=1.0,1.5$ いずれの場合も、樹 林帯上流端で最も土砂が堆積している。 $C_{D}$ の值が大 きい場合は、最大土砂堆積厚は増加するが、堆積範 囲は逆に隇少することが分かる。

次に、樹林帯密度入が堆砂形状に与える影瑤を調 べるため、 $\lambda$ と密生度 $\mathrm{a}$ のを変え、その他のパラ メータは固定して数值計算を行った。すなわち $\lambda=$ $0.0017, \mathrm{a}=0.0111(1 / \mathrm{cm})$ とした。このモデルは直径

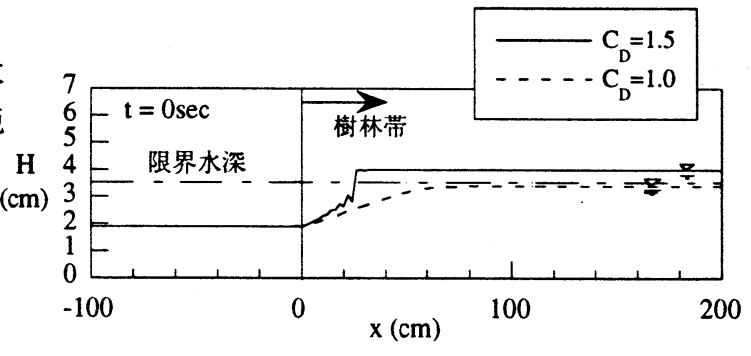

図 - 10 初期状態の水面形

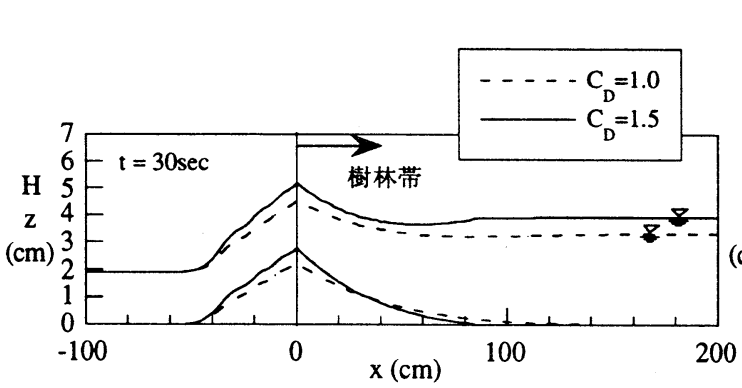

図 - 11 抗力係数を変化させた場合の堆砂形状

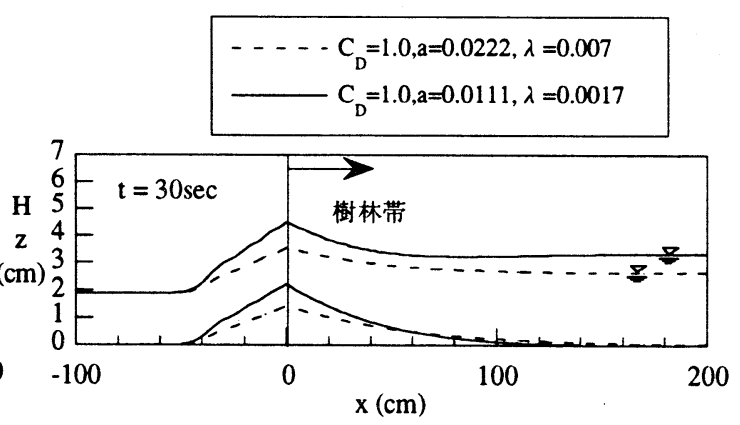

図-12樹林帯密度を变化させた場合の堆砂形状 
$2.0 \mathrm{~mm}$ の円柱を $6 \mathrm{~cm}$ 間隔で千鳥状に配置した樹林帯Eに相当する。つまり、樹木の配置は変えずに、樹木の 直径を半分にしたものである。計算結果を図 - 12に示す。樹林帯密度を小さくすると、最大土砂堆積厚は隇 少し、堆積範囲は下流へ延びることが分かる。また、計算結果の図 - 11 と実験結果の図 - 7とを比較すると、 樹林帯上流端で最大堆積高を示すなど、計算值は実験結果と定性的に一致している。しかしながら、計算 值は下に凸の、実験值は上に凸の堆砂形状を示すなど、両者で異なる傾向となっている。これは、計算に おいて土砂粒子の慣性的挙動などの非平衡性が考虑されていないためと考えられる。

\section{5. おわりに}

以上、樹林帯に作用する土砂・水混相流の抗力係数を調べるとともに、土砂の堆積特性を調べた。その 結果、樹林帯の抗力係数は清水流よりも混相流の場合の方が大きく、土砂濃度や樹林帯密度が増加するに つれ増加する傾向がある。また、樹林帯内の堆砂は時間の経過とともに下流側から上流側へと進行し、堆 砂の発生域は樹林帯密度が大きくなるにつれ下流側から上流側へと移動することが分かった。

また、樹林帯内における運動方程式と連続式をMacComack 法を用いて差分化し、掃流砂による1次元河 床変動計算を行った。また、抗力係数および樹林帯密度を変化させて堆砂形状への効果を調べた。堆砂形 状の計算は必ずしも実験結果を良好に説明するものではないが、樹林帯の特性を良く表している。今後は、 堆砂形状の精度の良好な計算法の開発、および浮流砂による河床変動計算を行っていく予定である。

最後に、本研究を行うに当たり、九州大学工学部の池松伸也技官には実験装置の製作などにおいて多大の 助力を受けた。当時九州大学工学部生の島廻健司氏には実験やデー夕整理において多大の助力を受けた。 また、本研究は一部、文部省科学研究費補助金基盤研究 (C)（課題番号08650612）の補助を受けている。こ こに記して感謝の意を表します。

\section{参考文献}

1) 溜水義久：阪神淡路地区の復興と課題、阪神・淡路大震災復興対策シンポジウム、土木学会誌、第81 巻、 第1号付録、1995.

2）阿部和時・岩元賢·三森利昭：樹林带の土砂流出防止機能について, 昭和 62 年度砂防学会研究発表会概 要集、 1987.

3）水山高久 - 天田高白 - 栗原淳一 - 小林幹男：樹林帯の抵抗特性と土砂堆積促進効果, 新砂防、vol. 42, No. 4, 1989.

4) H. Hashimoto and M. Hirano: Rapid flows of sand-water mixtures at high concentration in a steep channel, Advances in Micromechanics of Granular Materials, Elsevier Science Publishers B.V., 1992.

5）平野宗夫・橋本晴行・福富章・田熊幸二・パルームハマドサレー：開水路における高濃度流の無次元パ ラメーター, 水工学論文集、第36巻、1992.

6）橋本晴行 ·平野宗夫：掃流状集合流動の抵抗則と流砂量、土木学会論文集、No. 545/II-36、pp. 33-42, 1996. 